\title{
Habitat shifts in the evolutionary history of a Neotropical flycatcher lineage from forest and open landscapes Frank E Rheindt*1,2, Les Christidis ${ }^{1,3}$ and Janette A Norman ${ }^{2}$
}

\author{
Address: ${ }^{1}$ Department of Genetics, University of Melbourne, Parkville Campus, Melbourne VIC 3000, Australia, ${ }^{2}$ Population Ecology and Genetics \\ Unit, Sciences Department, Museum Victoria, 11 Nicholson St., Carlton VIC 3053, Australia and ${ }^{3}$ Australian Museum, 6 College Street, Sydney \\ NSW 2010, Australia \\ Email: Frank E Rheindt* - frankrheindt@yahoo.com.au; Les Christidis - Les.Christidis@austmus.gov.au; \\ Janette A Norman - jnorman@museum.vic.gov.au \\ * Corresponding author
}

Published: 7 July 2008

BMC Evolutionary Biology 2008, 8:1 193 doi:10.1 |86/147|-2|48-8-193
Received: 2 May 2008

Accepted: 7 July 2008

This article is available from: http://www.biomedcentral.com/I47I-2I48/8//93

(c) 2008 Rheindt et al; licensee BioMed Central Ltd.

This is an Open Access article distributed under the terms of the Creative Commons Attribution License (http://creativecommons.org/licenses/by/2.0), which permits unrestricted use, distribution, and reproduction in any medium, provided the original work is properly cited.

\begin{abstract}
Background: Little is known about the role ecological shifts play in the evolution of Neotropical radiations that have colonized a variety of environments. We here examine habitat shifts in the evolutionary history of Elaenia flycatchers, a Neotropical bird lineage that lives in a range of forest and open habitats. We evaluate phylogenetic relationships within the genus based on mitochondrial and nuclear DNA sequence data, and then employ parsimony-based and Bayesian methods to reconstruct preferences for a number of habitat types and migratory behaviour throughout the evolutionary history of the genus. Using a molecular clock approach, we date the most important habitat shifts.

Results: Our analyses resolve phylogenetic relationships among Elaenia species and confirm several species associations predicted by morphology while furnishing support for other taxon placements that are in conflict with traditional classification, such as the elevation of various Elaenia taxa to species level. While savannah specialism is restricted to one basal clade within the genus, montane forest was invaded from open habitat only on a limited number of occasions. Riparian growth may have been favoured early on in the evolution of the main Elaenia clade and subsequently been deserted on several occasions. Austral long-distance migratory behaviour evolved on several occasions.

Conclusion: Ancestral reconstructions of habitat preferences reveal pronounced differences not only in the timing of the emergence of certain habitat preferences, but also in the frequency of habitat shifts. The early origin of savannah specialism in Elaenia highlights the importance of this habitat in Neotropical Pliocene and late Miocene biogeography. While forest in old mountain ranges such as the Tepuis and the Brazilian Shield was colonized early on, the most important colonization event of montane forest was in conjunction with Pliocene Andean uplift. Riparian habitats may have played an important role in facilitating habitat shifts by birds expanding up the mountains along streams and adapting to newly emerging montane forest habitat.
\end{abstract}




\section{Background}

The major evolutionary mechanisms that have resulted in the Neotropical Region's extremely large and diverse fauna are not well understood. Most phylogenetic studies have concentrated on radiations that have diversified within Neotropical forests [1-9] and a few have dealt with radiations centered in open habitats such as grasslands and open scrub [10-13]. These studies have found that the most recent speciation events have occurred between geographically isolated populations inhabiting the same habitat type, suggesting that allopatric isolation through vicariance has been a dominant speciation mechanism $[1,3,6,9]$. A limitation in extrapolating from these studies is that most research has focussed on lineages that occur in different microhabitats within one single habitat type (e.g. terra firme forest, floodplain forest, montane forest). Additionally, suitable methods for the reconstruction of habitat preferences of ancestral lineages have been limited until recently [14]. What is lacking is data on radiations that include opposite ends of a spectrum of habitats, such as dense forest and open savannah. Such studies will provide insights into the evolutionary significance of habitat shifts following colonization of new habitats.

We investigated the evolutionary history of Neotropical Elaenia flycatchers (Aves; Tyrannidae) using both mitochondrial and nuclear DNA sequences. This genus is distributed over a range of forest and open habitats from Mexico and Hispaniola to the southern tip of South America $[15,16]$ (Figure 1; Table 1). While largely avoiding tropical lowland rainforest during the breeding season, the genus is represented in a variety of other dense forest habitats. In addition, the genus is widespread in scrubby and open tree habitats in both the Neotropical highlands and lowlands (Table 1). Austral long-distance migration is well represented in the genus $[15,16]$.

Our study included samples of all but one currently recognised species (Table 2) and focused on the reconstruction of ancestral habitat preferences using both parsimony and Bayesian approaches. We traced the preferences for certain habitat types throughout the evolutionary history of the genus, namely forest, savannah, and riparian habitat, and estimated relative rates of transition between the occupancy of those habitats. Additionally, we reconstructed migratory behavior of the ancestors of Elaenia to trace the origin of austral long-distance migration in the genus and assess its role in the diversification of the genus. These data, in addition to molecular clock dating of speciation events, were then used to derive conclusions about modes of speciation and the evolution of habitat preference in Elaenia.

\section{Results \\ Genetic characterization}

The aligned Fib5 sequences were 586 bp, 126 bp of which were variable among our samples and $86 \mathrm{bp}$ of which emerged as parsimony-informative. We detected one 5-bp deletion in the sequence of Capsiempis flaveola with respect to the in-group as well as eight indels within the in-group, five of which were parsimony-informative. Four parsimony-informative in-group indels could readily be mapped onto our concatenated tree (see below) as a single gain. The remaining indel constituted a 1-bp deletion in both samples of E. gigas, the sole sample of E. [obscura] sordida and the Bolivian sample of E. flavogaster, and required three independent gains. However, the phylogenetic utility of 1-bp deletions has previously been shown to be low in tyrannids [17].

The ND2 partition comprised 1088 bp (incl. up to $47 \mathrm{bp}$ from the flanking tRNA-Met region), with 493 bp being variable and 436 bp parsimony-informative. No anomalies were detected in the translations of the ND2 coding gene, suggesting that the ND2 sequences were of mitochondrial origin.

Chi-square tests of homogeneity of base frequencies across taxa did not show any evidence for base compositional bias (data not shown). Pairwise uncorrected ' $\mathrm{p}$ ' divergences were calculated for both partitions and those relevant for discussion are presented in Table 3. Saturation graphs with pairwise divergences plotted against the number of transitions/transversions for Fib5 and for all three codons of ND2 (not shown) did not reveal saturation.

\section{Phylogenetic relationships}

BI searches of the ND2 partition yielded the tree depicted in Figure 2. The MP analysis arrived at a consensus topology that was fully congruent with the BI tree (parameters listed in Table 4), although MP bootstrap support was often lower than BI posterior probabilities (Figure 2).

Only a limited number of nodes received high support in the MP and BI analyses of the Fib5 partition (tree parameters listed in Table 4). In all but one case, nodes supported by MP bootstrap (BS) values >80 were also supported by BI posterior probabilities (PP) of 100 (Figure 3). None of the nodes supported by Fib5 was in conflict with nodes in the ND2 tree (Figure 2).

In view of the low level of topological conflict between ND2 and Fib5 partitions, we opted to concatenate both datasets. MP and BI searches of the concatenated dataset yielded a well-resolved tree (Figure 3) that displayed almost no conflict to any of the nodes recovered in the ND2 and Fib5 analyses. The only exception involves the 


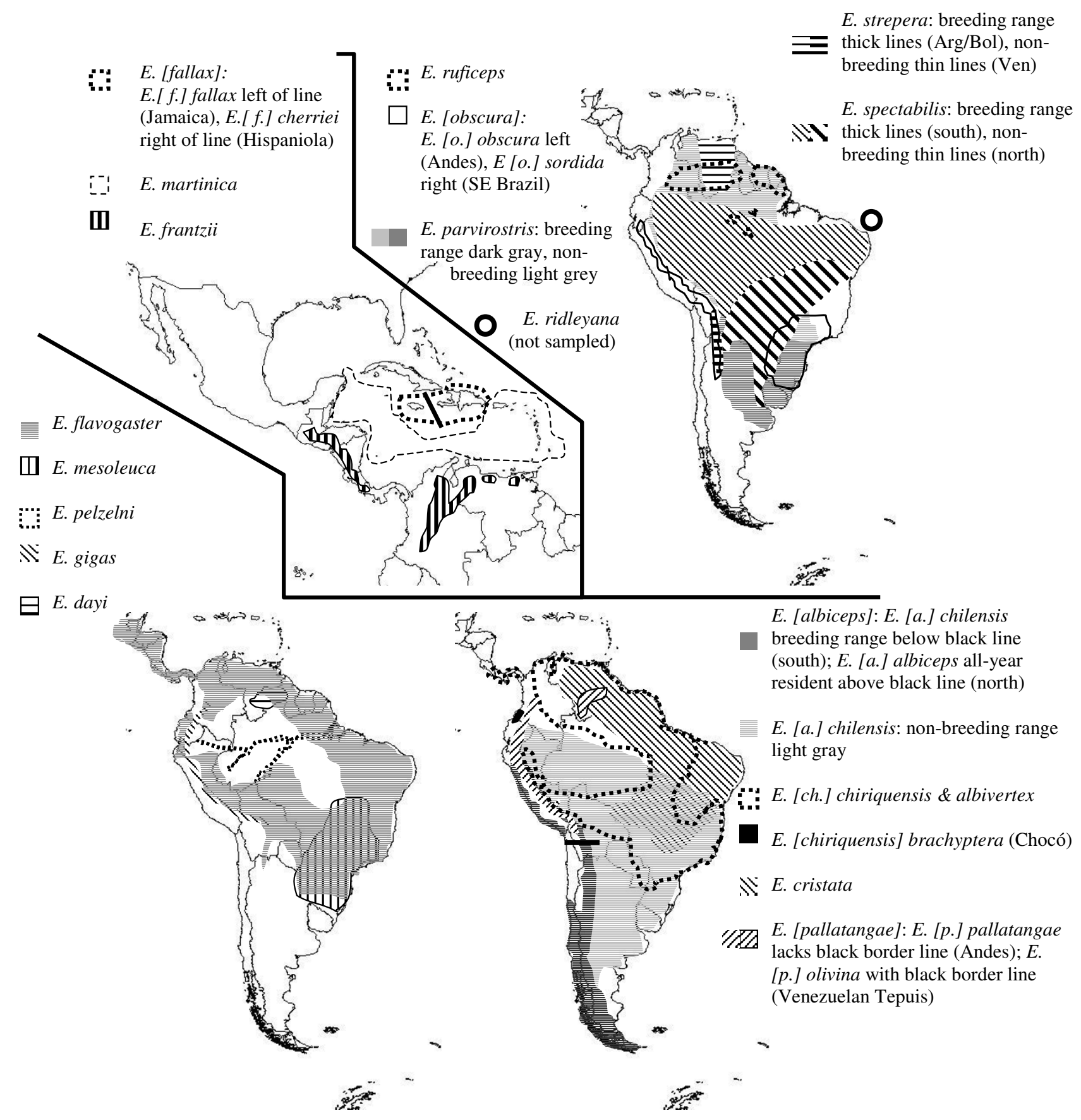

Figure I

Distribution maps for all species-level lineages in the genus Elaenia.

position of $E$. gigas, which is recovered as the sister group of the E. obscura/dayi super-species by BI analysis of the ND2 partition (Figure 2). However, neither MP analysis of that same partition (Figure 2), nor any type of analysis of the Fib5 partition (Figure 3) identified such a placement. Instead, concatenation of both partitions recovered $E$. gigas as basal to most other Elaenia species including the E. obscura/dayi super-species (Figure 3 ). It has previously been shown in tyrant-flycatchers that single markers routinely contain hidden phylogenetic signal that only unfolds once additional markers are added [17], and in view of the congruence of branch support between MP 
Table I: Wing-bar count and some ecological parameters for all species-level lineages of Elaenia sampled

\begin{tabular}{|c|c|c|c|c|}
\hline Taxon & Wing-bars & Movements & $\begin{array}{l}\text { Appr. preferred } \\
\text { breeding elevation }[\mathrm{m}]\end{array}$ & Preferred spectrum of breeding habitat \\
\hline E. martinica & 2 & sedentary & $0-1000$ & Scrub to forest \\
\hline E. flavogaster & 2 & $\begin{array}{l}\text { sedentary; some Mexican } \\
\text { populations migrate }\end{array}$ & $0-1500$ & $\begin{array}{l}\text { Scrub/savannah to light woodland, also } \\
\text { riparian growth }\end{array}$ \\
\hline E. spectabilis & 3 & austral migrant & $0-800$ & $\begin{array}{l}\text { Forest border and thickets, riparian growth } \\
\text { (heavier vegetation than E. flavogaster) }\end{array}$ \\
\hline E. albiceps & 2 & $\begin{array}{l}\text { austral migrant (E. a. chilensis) } \\
\text { and sedentary }\end{array}$ & $0-3300$ & Scrub to beech forest \\
\hline E. parvirostris & 3 & austral migrant & $0-1000$ & $\begin{array}{l}\text { Forest border to open areas, riparian } \\
\text { vegetation }\end{array}$ \\
\hline E. mesoleuca & 2 & $\begin{array}{l}\text { mostly sedentary, southern } \\
\text { populations migratory }\end{array}$ & $0-2000$ & Forest, gallery forest \\
\hline E. strepera & 2 & austral migrant & $500-2000$ & Forest border, streamside vegetation \\
\hline E. gigas & 2 & sedentary & $350-1500$ & Riparian growth, clearings \\
\hline E. pelzelni & 3 & sedentary & $0-200$ & $\begin{array}{l}\text { Riparian growth along Amazon, river-island } \\
\text { habitat }\end{array}$ \\
\hline E. cristata & 2 & $\begin{array}{l}\text { mostly sedentary, some } \\
\text { populations migratory }\end{array}$ & $0-1500$ & Savannah and cerrado \\
\hline E. [chiriquensis] albivertex & 2 & $\begin{array}{l}\text { mostly sedentary, some } \\
\text { populations migratory }\end{array}$ & $0-2000$ & $\begin{array}{l}\text { Scrub, cerrado, open woodland, riverine } \\
\text { vegetation }\end{array}$ \\
\hline E. [chiriquensis] brachyptera & 2 & sedentary & $700-2800$ & Forest border to lighter woodland \\
\hline E. ruficeps & 2 & sedentary & $0-1400$ & Cerrado, savanna, white-sand formations \\
\hline E. frantzii & 2 & $\begin{array}{l}\text { sedentary, some altitudinal and } \\
\text { latitudinal migration }\end{array}$ & $750-3600$ & Forest to borders \\
\hline E. [f.] fallax & 2 & sedentary & $500-2000$ & Forest to borders \\
\hline E. $[f$.$] cherriei$ & 2 & sedentary & $500-2000$ & Forest to borders \\
\hline E. [o.] obscura & 2 & sedentary & $1700-3000$ & Forest to woodland \\
\hline E. $[0$.$] sordida$ & 2 & sedentary & $0-2000$ & Forest to woodland \\
\hline E. dayi & 2 & sedentary & $1800-2600$ & Forest to stunted savanna \\
\hline E. [p.] pallatangae & 2 & sedentary & $1500-3000$ & Forest border to scrub \\
\hline E. [p.] olivina & 2 & sedentary & $900-2400$ & Forest border to scrub \\
\hline
\end{tabular}

Data from references $[15,16]$

and BI analyses of the concatenated dataset, we suggest that the position of E. gigas as depicted in Figure 3 reflects the most likely hypothesis based on our data. As a consequence of the strong topological agreement between the concatenated dataset and single partitions, phylogenetic discussion will be based on the tree resulting from the combined dataset (Figure 3).

\section{Ecological parameters and timing}

$\mathrm{MP}$ and $\mathrm{BI}$ reconstructions of ancestral migratory behavior and preferences for habitat types are presented in Figure 4 and Figure 5 and are explained more thoroughly in the Discussion. Transition rates between individual parameter states were not significant for any of the characters examined (not shown).

The likelihood score of the most likely tree computed under relaxed branch-length assumptions was not significantly different from that computed under conditions that enforce a molecular clock $\left(\chi^{2}=21.56, \mathrm{p}=0.36\right)$, which suggests that a molecular clock is a reasonable assumption for the evolution of Elaenia flycatchers as sampled in this study (Figure 6). We estimated the ages of Elaenia speciation events using a mitochondrial clock rate of $2 \%$ sequence divergence/MY for reasons provided in the Discussion. The temporal reconstruction of differentiation events in Elaenia is depicted in Figure 6.

\section{Discussion \\ Phylogenetic relationships within Elaenia and taxonomic conclusions}

All analyses identified two primary clades: (1) the two savannah specialists E. ruficeps and E. cristata which received high posterior probability; and (2) the remaining species with moderate Bayesian and parsimony support (Figure 3). Within the large clade there was strong support from the concatenated data for placing E. gigas as sister to the rest, which contradicts vocal data and crest shape that instead suggest a close relationship with E. flavogaster [16].

E. obscura, E. dayi and E. frantzii all lack the white coronal patch present in most other Elaenia species, and consequently have been treated as a super-species complex by some authorities [16]. While our data corroborate the pre- 
Table 2: Genbank accession numbers, genetic tissue numbers, institutions and collection localities of molecular specimens

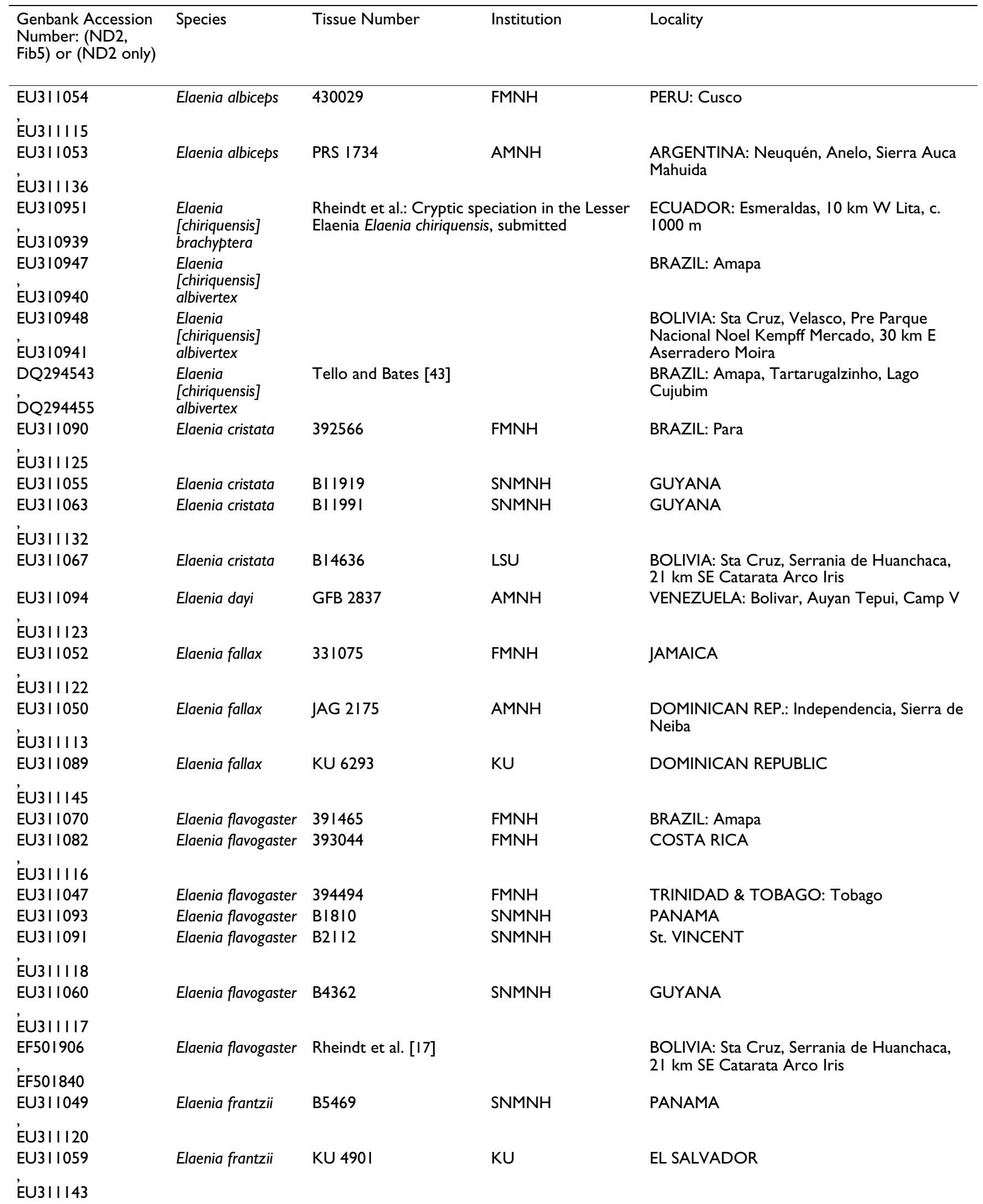


Table 2: Genbank accession numbers, genetic tissue numbers, institutions and collection localities of molecular specimens (Continued)

\begin{tabular}{|c|c|c|c|c|}
\hline EU3II092 & Elaenia gigas & 322868 & FMNH & PERU \\
\hline \multicolumn{5}{|l|}{ EU3IIII26 } \\
\hline EU3IIII00 & Elaenia gigas & B22898 & LSU & $\begin{array}{l}\text { BOLIVIA: La Paz, Prov. B. Saavedra, } 68 \text { km by } \\
\text { road E Charazani, Quita Calzon }\end{array}$ \\
\hline \multicolumn{5}{|r|}{ - } \\
\hline EU3।I088 & Elaenia martinica & B2116 & SNMNH & St. VINCENT \\
\hline \multicolumn{5}{|l|}{ EU3III24 } \\
\hline EU3II 079 & Elaenia martinica & NKK 784 & $\mathrm{AMNH}$ & $\begin{array}{l}\text { CAYMAN ISL.: Grand Cayman, Queens } \\
\text { Highway }\end{array}$ \\
\hline \multicolumn{5}{|r|}{ ( } \\
\hline $\begin{array}{l}\text { EU3। I } 057 \\
\text { EU3। II34 }\end{array}$ & Elaenia martinica & BII342 & LSU & $\begin{array}{l}\text { PUERTO RICO: Cabo Rojo, Llanos Costa, } 0.5 \\
\text { km NNW mouth Arroyo Cazul }\end{array}$ \\
\hline $\begin{array}{l}\text { EU3।I06I } \\
\text { EU3।II4I }\end{array}$ & Elaenia martinica & BII343 & LSU & $\begin{array}{l}\text { PUERTO RICO: Cabo Rojo, Llanos Costa, } 0.5 \\
\text { km NNW mouth Arroyo Cazul }\end{array}$ \\
\hline EU3। I 077 & Elaenia obscura & BI06786 & LSU & BOLIVIA: Beni, Serrania Pilon, I025 m \\
\hline $\begin{array}{l}\text { EU3। I } 083 \\
\text { EU3।II42 }\end{array}$ & Elaenia obscura & B8077 & LSU & $\begin{array}{l}\text { PERU: Pasco, Playa Pampa, } 8 \text { km NW Cushi } \\
\text { on trail to Chaglla }\end{array}$ \\
\hline $\begin{array}{l}\text { EU3। I } 087 \\
\text { EU3। II39 }\end{array}$ & Elaenia obscura & B38323 & LSU & $\begin{array}{l}\text { BOLIVIA: Sta Cruz, La Pajcha ca } 28 \text { km S } \\
\text { Samaipata }\end{array}$ \\
\hline $\begin{array}{l}\text { EU3।I096 } \\
\text { EU3। II44 }\end{array}$ & $\begin{array}{l}\text { Elaenia } \\
\text { pallatangae }\end{array}$ & GFB 2904 & $\mathrm{AMNH}$ & $\begin{array}{l}\text { VENEZUELA: Bolivar, Cerro Guanay, Camp } \\
\text { III }\end{array}$ \\
\hline $\begin{array}{l}\text { EU3। I } 095 \\
\text { EU3। II } 466\end{array}$ & $\begin{array}{l}\text { Elaenia } \\
\text { pallatangae }\end{array}$ & GFB 2960 & $\mathrm{AMNH}$ & $\begin{array}{l}\text { VENEZUELA: Amazonas, Cerro Yutaje, I } 700 \\
\mathrm{~m}\end{array}$ \\
\hline $\begin{array}{l}\text { EU3। I } 048 \\
\text { EU3। I I } 47\end{array}$ & $\begin{array}{l}\text { Elaenia } \\
\text { pallatangae }\end{array}$ & B8I55 & LSU & $\begin{array}{l}\text { PERU: Pasco, Playa Pampa, } 8 \text { km NW Cushi } \\
\text { on trail to Chaglla }\end{array}$ \\
\hline $\begin{array}{l}\text { EU3।IIOI } \\
\text { EU3।II48 }\end{array}$ & $\begin{array}{l}\text { Elaenia } \\
\text { pallatangae }\end{array}$ & B3 I 835 & LSU & $\begin{array}{l}\text { PERU: Cajamarca, Quebrada Lanchal, } 8 \text { km } \\
\text { ESE Sallique }\end{array}$ \\
\hline $\begin{array}{l}\text { EU3।I08I } \\
\text { EU3।III4 }\end{array}$ & $\begin{array}{l}\text { Elaenia } \\
\text { parvirostris }\end{array}$ & 334473 & \multicolumn{2}{|c|}{ EU3। וII4 } \\
\hline EU3III075 & $\begin{array}{l}\text { Elaenia } \\
\text { parvirostris }\end{array}$ & ALP I42 & $\mathrm{AMNH}$ & $\begin{array}{l}\text { BOLIVIA: Santa Cruz, Comunidad Karapari, } \\
\text { Estancia San Julian, } 1000 \mathrm{~m} \mathrm{~W} \text { of Rio Parapeti }\end{array}$ \\
\hline EU3।I I084 & $\begin{array}{l}\text { Elaenia } \\
\text { parvirostris }\end{array}$ & B5910 & SNMNH & ARGENTINA \\
\hline EU3।II073 & $\begin{array}{l}\text { Elaenia } \\
\text { parvirostris }\end{array}$ & JWW 278 & $\mathrm{AMNH}$ & $\begin{array}{l}\text { BOLIVIA: Santa Cruz, Comunidad Karapari, } \\
\text { Estancia San Julian, } 1000 \mathrm{~m} \mathrm{~W} \text { of Rio Parapeti }\end{array}$ \\
\hline EU3II062 & $\begin{array}{l}\text { Elaenia } \\
\text { parvirostris }\end{array}$ & KU 3417 & KU & PARAGUAY \\
\hline EU3। I068 & $\begin{array}{l}\text { Elaenia } \\
\text { parvirostris }\end{array}$ & PRS I099 & $\mathrm{AMNH}$ & ARGENTINA: Buenos Aires, Partido Escobar \\
\hline EU3।II076 & $\begin{array}{l}\text { Elaenia } \\
\text { parvirostris }\end{array}$ & B7268 & LSU & $\begin{array}{l}\text { PERU: Loreto, Amazonas Isla Pasto, } 80 \text { km } \\
\text { NE lquitos, } 80 \mathrm{~m}\end{array}$ \\
\hline EU3II064 & $\begin{array}{l}\text { Elaenia } \\
\text { parvirostris }\end{array}$ & ANSP I405 & ANSP & ECUADOR: Santiago, $400 \mathrm{~m}$ \\
\hline EU3।II072 & $\begin{array}{l}\text { Elaenia } \\
\text { parvirostris }\end{array}$ & ANSP 10253 & ANSP & $\begin{array}{l}\text { URUGUAY: I7 km N Ruta } 20 \text { KM4I, Rio } \\
\text { Negro }\end{array}$ \\
\hline EU3। I07I & $\begin{array}{l}\text { Elaenia } \\
\text { parvirostris }\end{array}$ & ANSP 10258 & ANSP & $\begin{array}{l}\text { URUGUAY: Maldonado, ca } 3 \text { km NE Pan de } \\
\text { Azucar }\end{array}$ \\
\hline $\begin{array}{l}\text { EU3। I } 074 \\
\text { EU3। II40 }\end{array}$ & $\begin{array}{l}\text { Elaenia } \\
\text { parvirostris }\end{array}$ & ANSP 10272 & ANSP & URUGUAY: Canelones, El Pinar \\
\hline EU3।II080 & Elaenia pelzelni & B7320 & LSU & $\begin{array}{l}\text { PERU: Loreto, Amazonas Isla Pasto, } 80 \text { km } \\
\text { NE Iquitos, } 80 \mathrm{~m}\end{array}$ \\
\hline
\end{tabular}


Table 2: Genbank accession numbers, genetic tissue numbers, institutions and collection localities of molecular specimens (Continued)

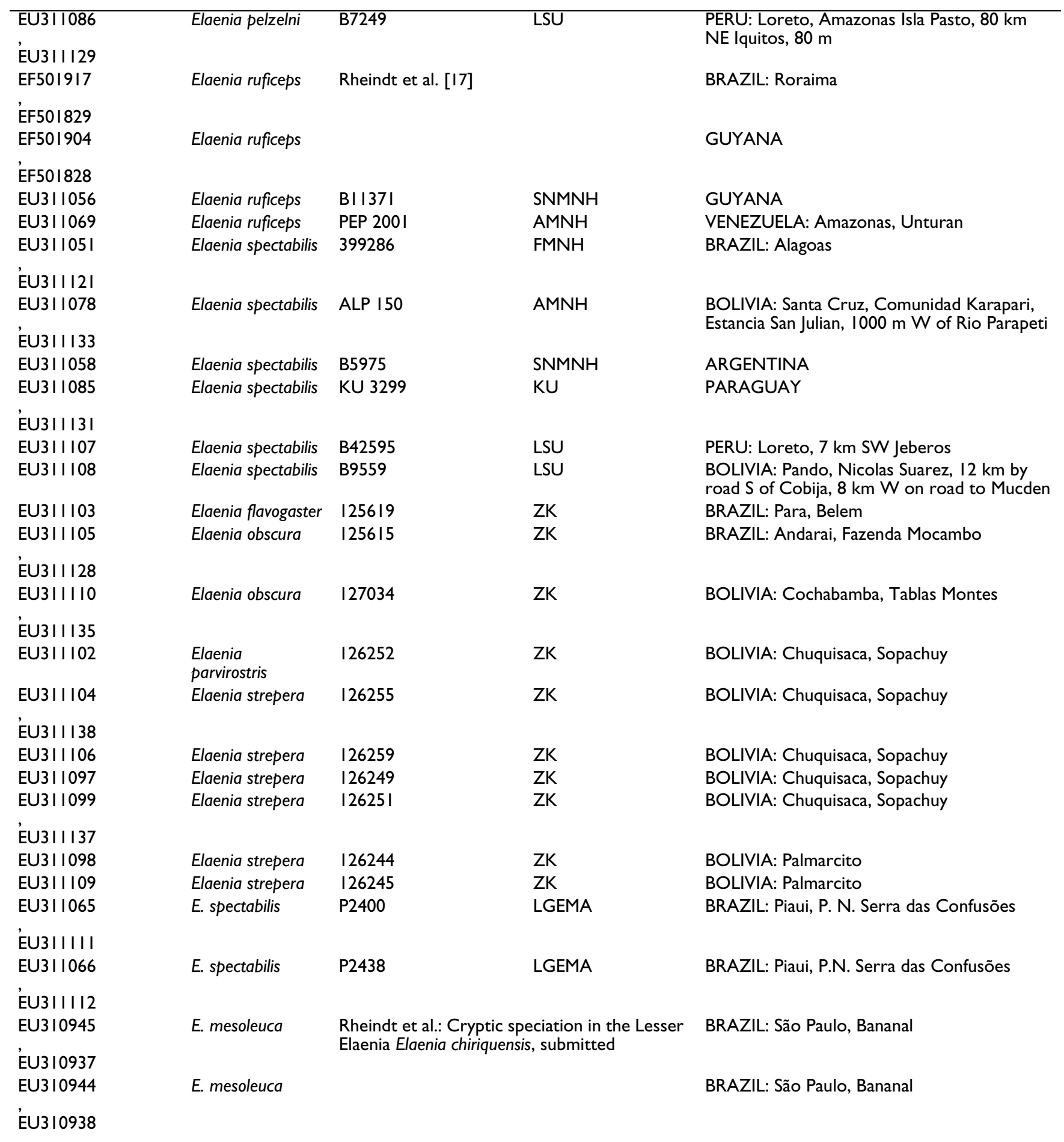

Literature references rather than genetic tissue numbers and institutions are given for samples from other studies; abbreviations: FMNH - Field Museum of Natural History, Chicago; AMNH - American Museum of Natural History, New York; SNMNH - Smithsonian National Museum of Natural History, Washington, D.C.; LSU - Louisiana State University Museum of Natural History, Baton Rouge, Louisiana; KU - Kansas University Museum of Natural History, Lawrence, Kansas; ANSP - Academy of Natural Sciences in Philadelphia; ZK - Zoological Museum of the University of Copenhagen; LGEMA - Laboratório de Genética e Evolução Molecular de Aves, São Paulo. 
Table 3: uncorrected ' $p$ ' divergences of the ND2 partition for inter- and intra-taxon comparisons

\begin{tabular}{|c|c|}
\hline comparison & $\begin{array}{l}\text { ND2 uncorrected } \\
\text { 'P' divergence [\%] }\end{array}$ \\
\hline E. spectabilis $\leftrightarrow$ E. pelzelni & $3.5-4.4$ \\
\hline E. [f.] fallax $\leftrightarrow E$. [f.] cherriei & $5.1-5.3$ \\
\hline within $E$. [f.] cherriei & 0.1 \\
\hline $\begin{array}{l}\text { E. martinica caymanensis (Cayman Is.) } \leftrightarrow \text { other } E \text {. } \\
\text { martinica }\end{array}$ & 1.4 \\
\hline $\begin{array}{l}\text { E. martinica riisii (Puerto Rico) } \leftrightarrow \text { E. m. martinica } \\
\text { (St. Vincent) }\end{array}$ & 0.2 \\
\hline E. martinica riisii within Puerto Rico & 0 \\
\hline E. dayi $\leftrightarrow E .[0$.$] obscura$ & $3.8-4.2$ \\
\hline E. dayi $\leftrightarrow E$. [obscura] sordida & 4.6 \\
\hline E. [o.] obscura $\leftrightarrow E$. [o.] sordida & $3.0-3.1$ \\
\hline within E. [o.] obscura & $0.1-0.3$ \\
\hline$E .[p$.$] pallatangae \leftrightarrow E$. $[p$.$] olivina$ & $7.1-7.3$ \\
\hline E. albiceps $\leftrightarrow E .[p$.$] pallatangae$ & 0.6 \\
\hline E. albiceps $\leftrightarrow E$. [p.] olivina & $6.9-7.0$ \\
\hline within E. albiceps & 0.4 \\
\hline within $E .[p$.$] olivina$ & 0.2 \\
\hline within $E .[p$.$] pallatangae$ & 0.2 \\
\hline
\end{tabular}

sumed close relationship between E. obscura and E. dayi [18], they strongly reject the inclusion of $E$. frantzii in this complex. The mitochondrial divergences between Andean E. o. obscura and Atlantic E. o. sordida are comparable to those between sister species of Elaenia (e.g. E. spectabilis and E. pelzelni; Table 3), and are ten times higher than divergences within E. o. obscura sampled from along a $1500 \mathrm{~km}$ Andean transect. Furthermore, E. o. obscura and E. o. sordida did not always form a monophyletic clade with respect to E. dayi (Figure 3 ) and are best treated as separate species: E. obscura and E. sordida.

Our analyses confirmed the genetic distinctness of $E$. [chiriquensis] brachyptera with respect to $E$. [chiriquensis] albivertex and their treatment as separate species (Rheindt et al.: Cryptic speciation in the Lesser Elaenia Elaenia chiriquensis, submitted). Deep genetic divisions were also observed in E. fallax. The level of ND2 divergence between Jamaican E. f. fallax and Hispaniolan E. f. cherriei exceeded that recorded between other species of Elaenia, suggesting long-term separation and species-level treatment for $E$. cherriei (Table 3; Figure 2).

E. parvirostris has usually been allied with E. albiceps, based on vocal and morphological grounds, and apparent hybridisation $[16,19]$. Both mitochondrial and nuclear sequences placed the two in unrelated clades; E. parvirostris in a clade consisting primarily of migratory lowland species, and E. albiceps in a clade with E. pallatangae (Figure 3). Given that E. parvirostris is also a lowland migratory species, its phylogenetic placement here is consistent with its ecology. Furthermore, it also shares with other members of this clade (E. spectabilis, E. pelzelni) three (as opposed to the usual two) wing-bars. The placement of $E$. parvirostris and E. albiceps in two relatively distant clades calls for a re-examination of the potential hybrid zone in southern Bolivia [19].

E. albiceps is also thought to hybridise with E. pallatangae [18]. The five recognised subspecies of $E$. pallatangae are distributed over two discrete South American land areas: the Andes and the Venezuelan Tepuis (Figure 1). All our Venezuelan samples (E. [p.] olivina) formed a distinct clade closely related to a number of Central American and Caribbean Elaenia species, while the Andean samples ( $E$. pallatangae sensu stricto) emerged in a clade with E. albiceps and were scarcely distinguishable from the latter in both mitochondrial and nuclear DNA (Figure 3). Clearly, more detailed sampling is needed to resolve this unusual phylogenetic pattern. Future research may reveal that E. albiceps and E. pallatangae sensu stricto may be conspecific, or that genetic introgression has accounted for their similar mitochondrial DNA, and the current taxonomic status of the latter two forms is best retained until such studies have been conducted. Nevertheless, the phylogenetic divergence between E. [p.] pallatangae and E. [p.] olivina on both nuclear and mitochondrial DNA indicates treatment of E. olivina as a species that is not particularly closely related to Andean E. pallatangae.

Some reasonably deep mitochondrial divergence was found between the Cayman Island subspecies caymanensis of E. martinica and the other two subspecies investigated (Table 3). In contrast, samples of E. martinica riisii from Puerto Rico and E. m. martinica from St. Vincent were barely distinguishable from one another on ND2 divergences (Table 3). This suggests a close affinity of the latter two subspecies, which are geographically linked through the Lesser Antillean island chain. The Cayman Island race is geographically isolated, with sequence divergences typical of distinct tyrannid subspecies [17].

\section{Habitat shifts in the evolutionary history of Elaenia}

Our reconstructions of ancestral habitat requirements revealed pronounced differences not only in the timing of the emergence of certain habitat preferences, but also in the frequency of habitat shifts (Figure 4). In the following, we will examine these habitat shifts individually for each habitat considered.

\section{Savannah}

Elaenia includes two habitat specialists (E. ruficeps and E. cristata) that are closely tied to the occurrence of natural savannah and cerrado. Our DNA phylogeny (Figure 3) united these two in a clade that was sister to the remaining species of Elaenia. Zimmer [18] also identified features of the wing formula and nostril structure that separated $E$. 


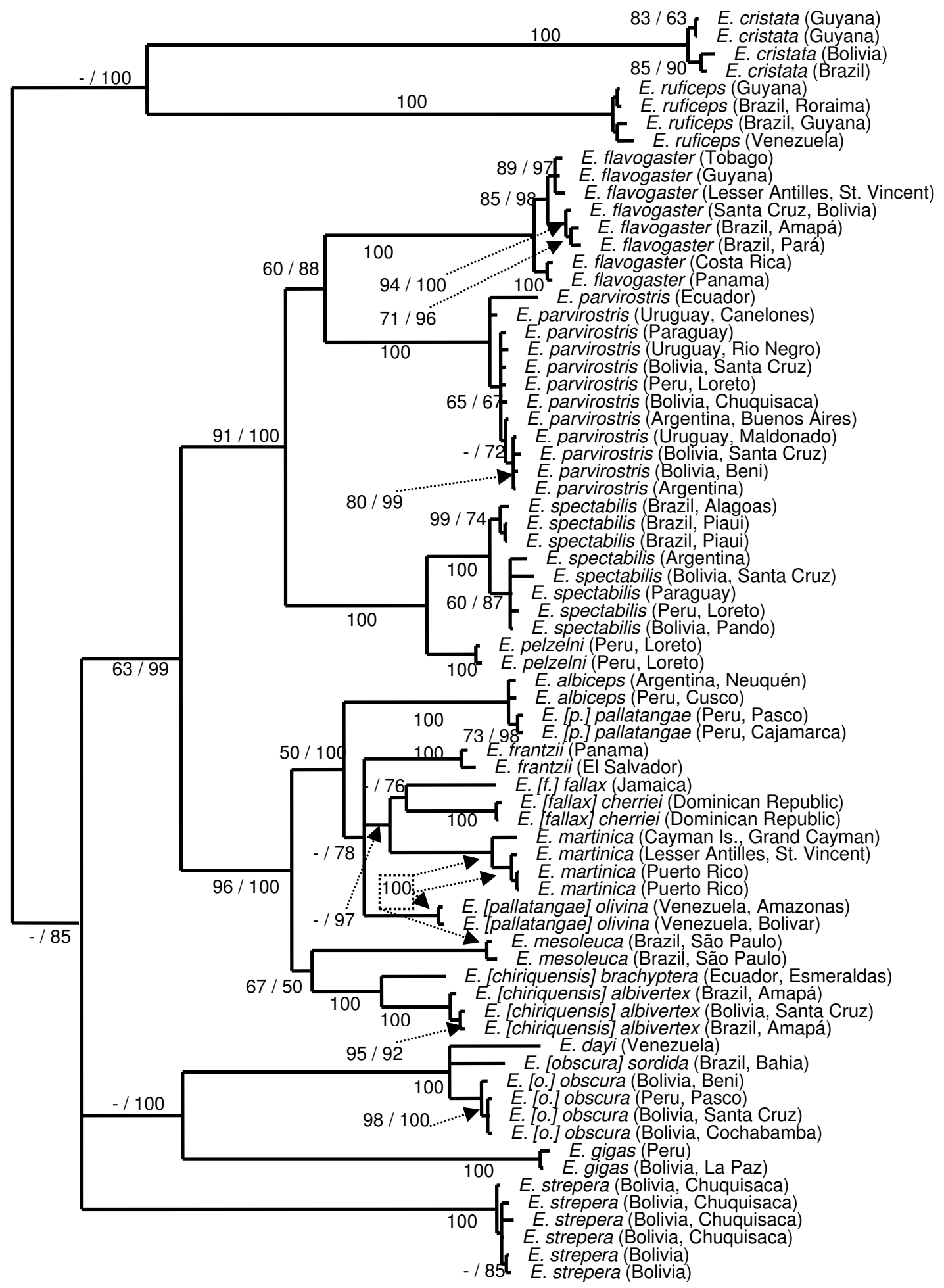

Figure 2

Bayesian tree of the ND2 partition; numbers at nodes indicate parsimony bootstrap (BS; left) and Bayesian posterior probability (PP; multiplied by 100 ; right) values; bold numbers indicate equal support by both types of analysis; only values of BS > 60 and $P P>60$ are shown. 
Table 4: Maximum-parsimony tree and evolutionary model parameters, Bayesian burn-in specifications for both individual data partitions and for the combined dataset

\begin{tabular}{llll}
\hline Partition & ND2 & Fib5 & Concatenated \\
\hline Score of MP trees & 1578 & 174 & 1610 \\
Consistency index of MP trees & 0.407 & 0.759 & 0.475 \\
Retention index of MP trees & 0.844 & 0.883 & 0.779 \\
Best evolutionary model (-InL) & TrN+G $(7887.163 \mathrm{I})$ & $\mathrm{HKY}+\mathrm{G}(1937.5226$ & $\mathrm{n} / \mathrm{a}$ \\
Base frequencies (A, C, G) & $0.3089,0.3089,0.0922$ & $0.2902,0.1695,0.2296$ & $\mathrm{n} / \mathrm{a}$ \\
Transition/transversion ratio & $\mathrm{n} / \mathrm{a}$ & $\mathrm{n} / \mathrm{a}$ \\
Substitution rate matrix (AC, AG, AT, CG, CT) & $1,29.441 \mathrm{I}, \mathrm{I}, \mathrm{I}, 15.1094$ & $\mathrm{n} / \mathrm{a}$ & $\mathrm{n} / \mathrm{a}$ \\
Gamma shape parameter & 0.2632 & 0.3180 & $\mathrm{n} / \mathrm{a}$ \\
Proportion of invariable sites & 0 & 0 & $\mathrm{n} / \mathrm{a}$ \\
Burn-in of Bayesian analysis & 100,000 & 10,000 & 75,000 \\
\hline
\end{tabular}

Abbreviations: MP - most-parsimonious, n/a - not applicable

ruficeps and E. cristata from the rest of the genus. Three other species regionally breed in savannah habitat, though they are more generalist in nature and occur in other habitat types as well (Table 1). E. flavogaster and E. chiriquensis are widespread denizens of a variety of open habitats, while E. dayi is primarily a forest bird that also breeds in stunted tree savannah within its restricted range in the Venezuelan Tepuis $[15,16]$. These facultative savannah inhabitants did not form a clade and were positioned in different assemblages.

The finding that savannah specialists are sister to the rest of Elaenia suggests that savannah would have constituted an important part of the Neotropical landscape during the early diversification of the genus. Although parameter state reconstructions are either equivocal (MP) or argue against (BI) a savannah-inhabiting ancestor of Elaenia, savannah is likely to have been invaded by proto-ruficeps/ cristata shortly after the initial divergence of Elaenia (Figure 4).

\section{Forest interior}

Elaenia is widely distributed throughout Neotropical edge habitats and other open vegetation and avoids tropical lowland rainforests $[15,16]$. Nevertheless, a number of species are found primarily or secondarily in the interior of montane or otherwise temperate forest (Table 1). Even though nine species inhabit forest, both Bayesian and parsimony state reconstructions showed that occurrence in forest interior arose on only two or three (maximally four) occasions (Figure 4). Within these assemblages of forestinhabiting species, the prevailing pattern is one of allopatric distributions (Figure 1). This is consistent with the notion that geographical isolation rather than ecological divergence is the most common mode of speciation in Neotropical birds $[1,3,6,9]$.

\section{Riparian habitats}

Almost half of the species of Elaenia are either narrowly confined to riparian vegetation or have a regional preference for it. Riparian habitat preferences can vary widely from montane streamside habitat (e.g. E. strepera) to Cecropia stands on Amazonian river-islands (E. pelzelni), but a frequent commonality of these habitats is that they constitute breaks in blocks of closed forest habitat or savannah/cerrado. Both MP and BI reconstructions indicated that an association with riparian growth may have been prevalent in the main lineage of Elaenia in very early stages of its diversification and may have been lost on at least two to four occasions (Figure 4). Two of these secondary losses of riparian association involve lineages that subsequently colonized forest interior where they diversified extensively (the E. obscura/dayi complex and the "montane forest clade" of Figure 3). River and stream association may have provided an evolutionary vehicle for lowland species of open habitat to move up the streams and colonize montane forest. This notion is further supported by the fact that the most basal riparian species $E$. gigas (Figure 3 ) is confined to the Andean foothills while many subsequent speciation events gave rise to lineages that occur in elevationally higher regions.

It is intriguing that although the ancestor of Elaenia was able to colonize montane forest, it never gained a foothold in tropical lowland forest. Brumfield and Edwards [3] suggested that competitive interspecific interactions may limit colonization potential in the evolution of Neotropical suboscines. Accordingly, Elaenia may have been able to exploit new montane forests formed by mountain uplift, while being excluded from the older lowland forests through competitive interactions with other flycatchers.

\section{Evolutionary history of migratory behavior in Elaenia}

Some species of Elaenia are austral migrants that breed in the temperate zone of the southern Neotropics and move 


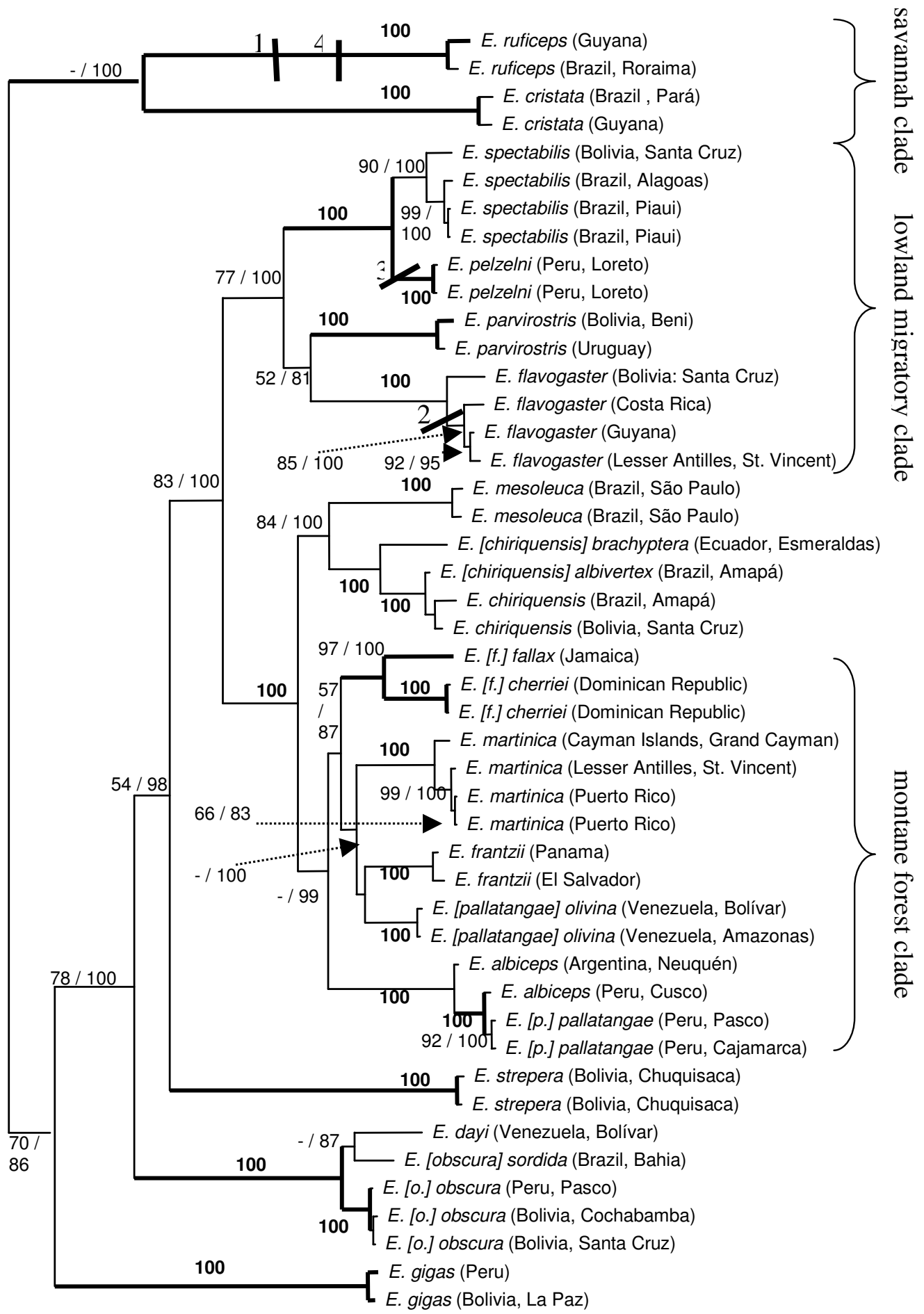

Figure 3

Bayesian tree of the concatenated dataset; numbers at nodes indicate parsimony bootstrap (BS; left) and Bayesian posterior probability (PP; multiplied by 100; right) values; bold numbers indicate equal support by both types of analysis; only values of BS > 50 and PP > 80 are shown; thick branches additionally received high support in Fib5 analyses (BS > 80; PP = I00, except for the node uniting all three $E$. [0.] obscura, which only received a PP $=96$ ); numbered cross-bars at nodes refer to parsimonyinformative Fib5 indels mapped onto tree: I.) 10-bp insertion, 2.) I-bp deletion, 3.) I-bp insertion, 4.) I-bp deletion. 


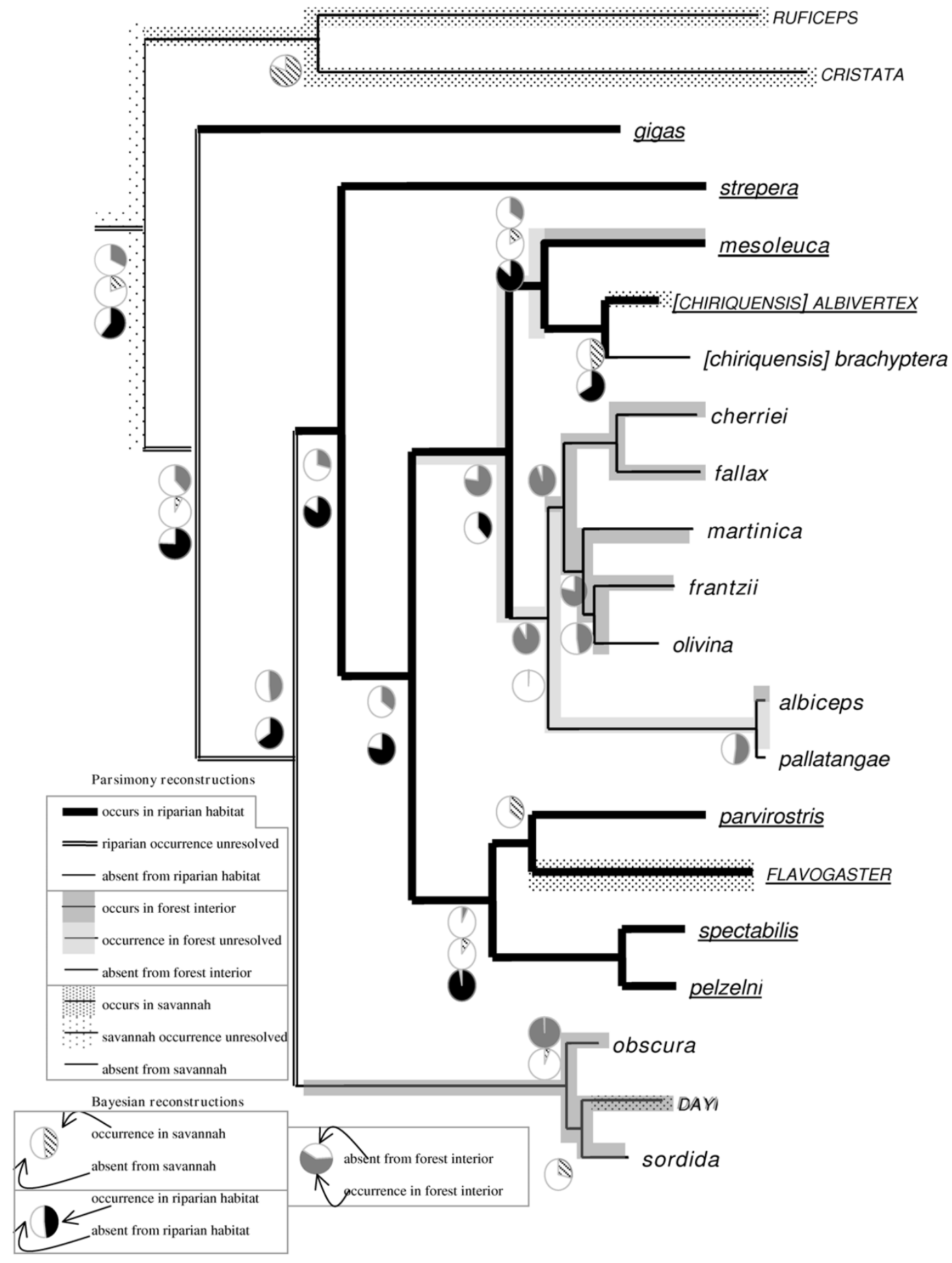

Figure 4

Occurrence in forest interior, natural savannah/cerrado and riparian habitats mapped onto the Elaenia tree topology derived from concatenated dataset with species-level lineages reduced to one representative; species occurring in forest interior are printed bold; species occurring in SAVANNAH are capitalized; species occurring in riparian habitats are underlined; line thickness and line background color refer to parsimony reconstructions; pie charts (only shown for nodes relevant for discussion) refer to Bayesian reconstructions. 


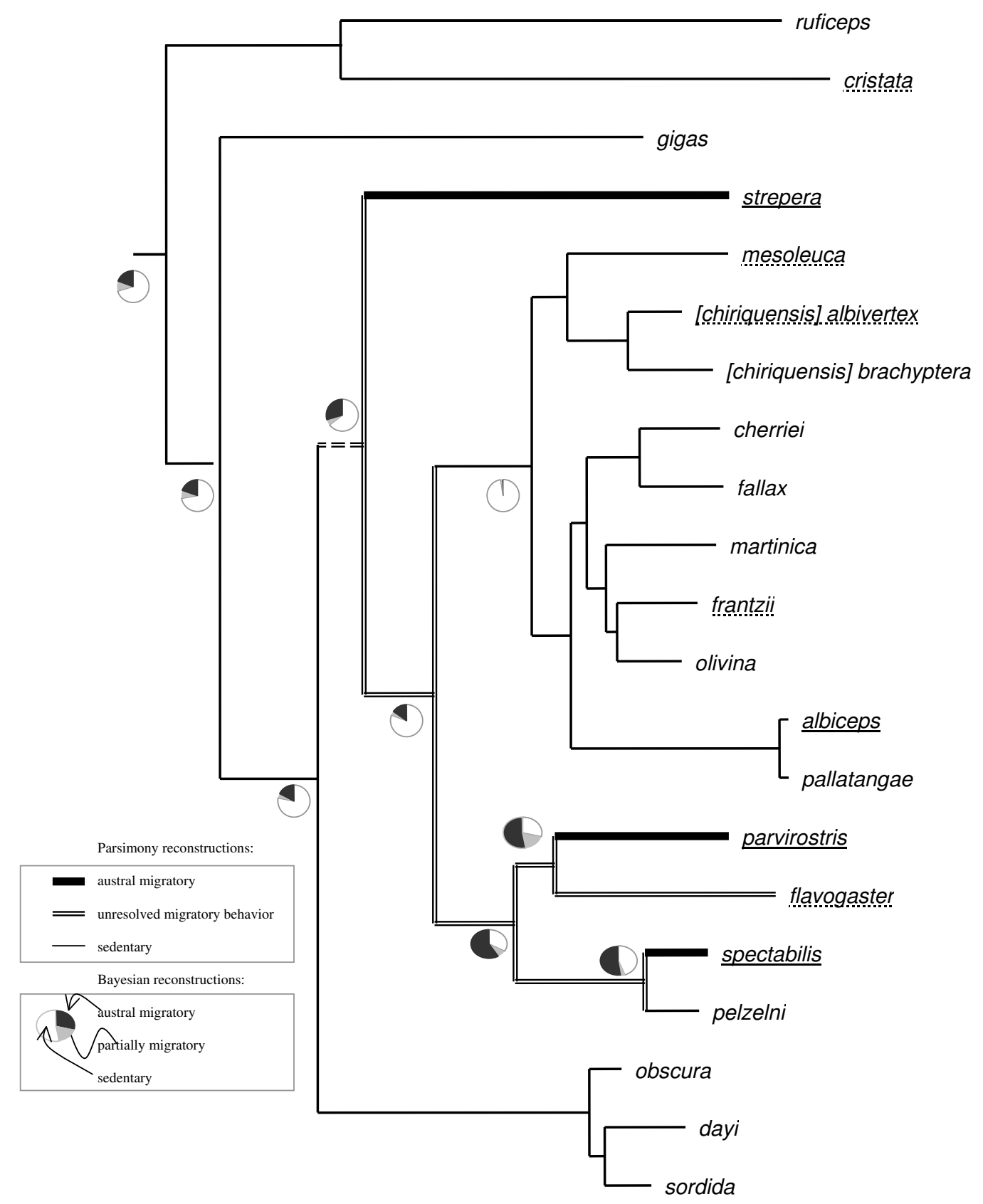

Figure 5

Migratory behavior mapped onto the Elaenia tree topology derived from concatenated dataset with specieslevel lineages reduced to one representative;austral migrant species are underlined with a solid line, partially migratory species are underlined with a broken line; sedentary species are not underlined; line thickness refers to parsimony reconstructions; pie charts (only shown for nodes relevant for discussion) refer to Bayesian reconstructions.

to the tropics in the austral winter (Table 1). Such migratory behavior is ordinarily displayed by the entire species (E. spectabilis, E. parvirostris, E. strepera), though in E. albiceps only the southern race E. $a$. chilensis migrates while more northerly races are sedentary. In addition, Elaenia contains five "partially migratory species" that are seden- tary over most parts of their range but do exhibit short-distance migratory behavior in some of their more temperate populations (Table 1). MP and BI reconstructions both indicated a sedentary ancestor of Elaenia with migratory and partial migratory behavior arising several times (Figure 5). This result is in agreement with Joseph et al.'s [20] 


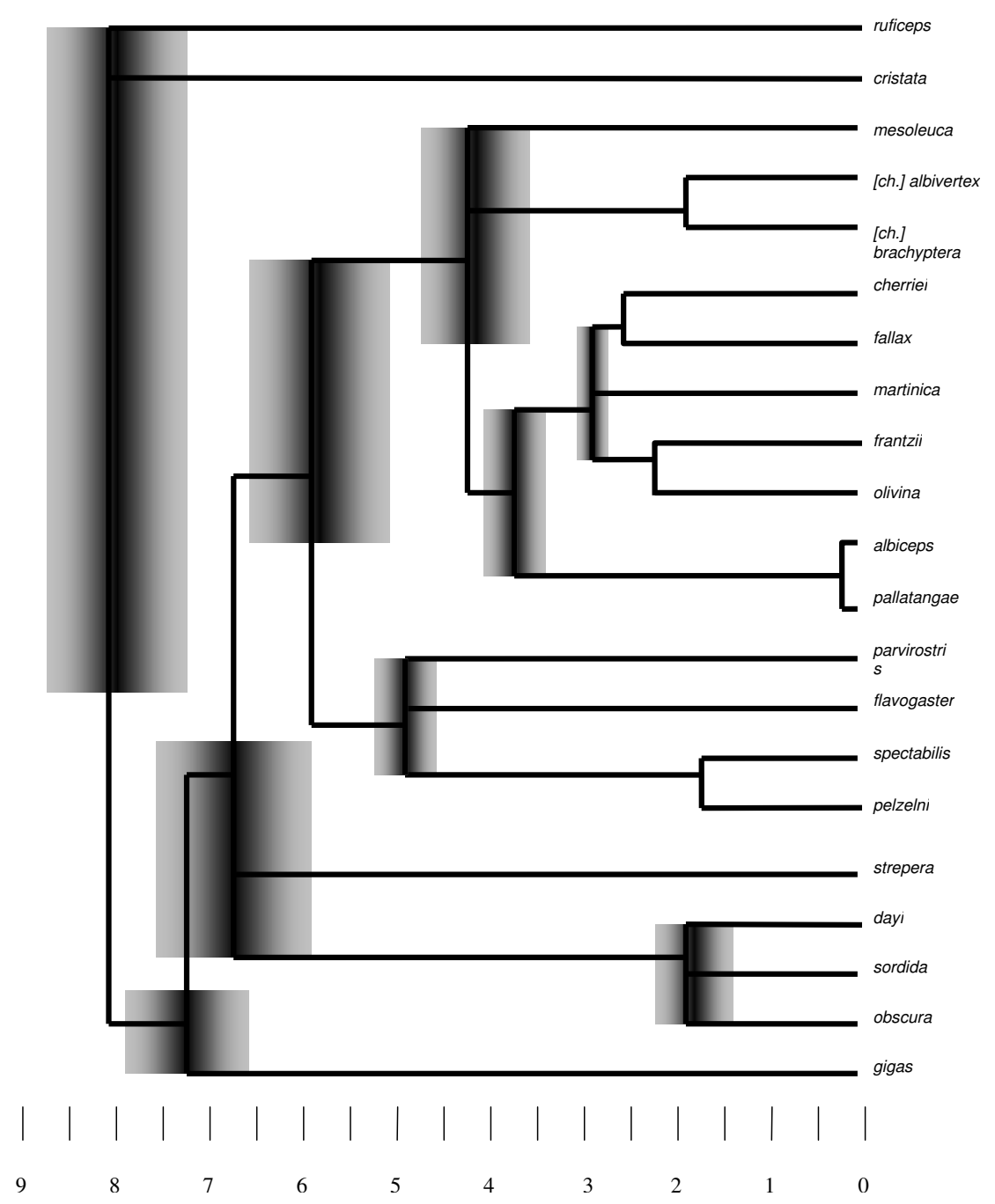

Figure 6

Age estimates of Elaenia speciation events mapped onto the concatenated tree topology using a $2 \% / m i l l i o n$ years (MY) molecular clock rate; scale in MY; error bars at nodes refer to divergence range between taxa; neighboring nodes were merged in cases where both upper and lower divergence bound of one node falls inside the range of the neighbour; scale at bottom indicates millions of years before present.

phylogenetic analysis of migratory behavior in Myiarchus flycatchers. The fact that austral long-distance migration exists in some populations of species that are otherwise sedentary, and the high incidence of partial migration in Elaenia species, suggest that migratory behavior is evolutionarily labile in tyrannids.

From our phylogenetic reconstructions there is one possible example of speciation resulting from loss of migratory behaviour. E. pelzelni is the only sedentary habitat specialist of a clade that comprises either migratory or partially migratory habitat generalists (Figures 3, 4). Although neither mode of reconstruction unequivocally identified an austral migratory ancestor to this clade, ecological evi- dence suggests that E. pelzelni is likely derived from an austral migrant ancestor. E. pelzelni has very specific habitat requirements (river-island habitat along the Amazon), and considering the migratory generalist life histories of all other members of this clade, it is very unlikely for the ancestor of E. pelzelni and E. spectabilis to have been a sedentary specialist. Though dispersing widely, wintering populations of E. spectabilis avoid the interior of tropical rainforest, frequenting instead marginal and riparian habitats. An ancestor with a similar behaviour could therefore have easily given rise to a sedentary riparian E. pelzelni. 


\section{The timing of Elaenia diversification}

Dating of evolutionary events has presented major difficulties in phylogeographic studies of birds. The sparse avian fossil record (especially of songbirds) complicates the assessment of the age of certain lineages. Instead, phylogeneticists have resorted to the notion of a molecular clock to date speciation events (for a summary, see $[21,22])$. However, the constancy and universality of a traditional avian mitochondrial molecular clock of c. $2 \%$ divergence/MY has been questioned [21-23], and rate constancy has been contradicted by Bayesian reconstructions using calibrations at the level of avian orders and vertebrate classes [24]. Nevertheless, a large number of avian clock calibrations provided for phylogeographic studies at the genus level seem to converge at around 2\%/ MY (e.g. [25-28]). More importantly, Weir and Schluter [29] used cross-validation techniques to compare 90 candidate avian clock calibrations dating back overwhelmingly to the genus level and found strong support for a $2.1 \% / \mathrm{MY}$ clock rate constant over the last $12 \mathrm{MY}$ and universal across twelve bird orders. In tyrannid flycatchers in particular, Rheindt et al. (The timing of Neotropical speciation dynamics: a reconstruction of Myiopagis flycatcher diversification using phylogenetic and paleogeographic data, submitted) compared mitochondrial molecular clock rates from the literature with paleogeographic calibrations of ND2 sequences within a closely related elaeniid flycatcher genus (Myiopagis), and found that the traditional avian molecular clock of $2 \%$ mtDNA divergence/MY is a reasonable assumption for elaeniid ND2 sequences. Based on these considerations, we have used a mitochondrial clock rate of $2 \% / \mathrm{MY}$ to date speciation events in Elaenia (Figure 6). We emphasize that these dating estimates can only be viewed as an approximation, and we only discuss them in the rough timeframe of earthhistorical epochs.

According to our reconstructions, the earliest divergences occurred in rapid succession in the late Miocene (c. 8.5 to 5.3 MYA). Arising during this period were the two savannah specialists as well as E. gigas, E. strepera, the E. obscura/ dayi complex, the migratory lowland clade (Figure 2), and the lineage comprising all the remaining species. The Amazon lowlands at that time were intermittently flooded by "Lago Amazonas", an extensive spatially and temporally variable freshwater lake system that drained into the Caribbean (see [30] and references therein). The landscape constituted "...a vast complex of shallow megalakes surrounded by swampy grassland savanna..." interspersed with forest (p. 206 in [30]). Such a dynamic savannah-forest landscape with water barriers rapidly changing in extent was likely conducive for vicariant speciation events such as those that led to the two savannah specialists and the migratory lowland lineage (Figure 3 ). The Andes at that time were only about a third to half of their current elevation [31,32]. Consequently, the montane Elaenia lineages that had emerged by that time were either Andean foothill species (e.g. E. gigas) as opposed to Andean highland species, or were clades from ancient Neotropical mountain shields such as E. dayi from the Tepuis or E. sordida from the Brazilian Shield, which may have given rise to Andean E. obscura at a much later date.

With the onset of the Pliocene at c. 5 MYA, there was a second wave of speciation events which commenced with the differentiation of the lowland migratory clade (Figure 3) into its three main lineages, two of which include austral breeders that annually migrate into the tropics (E. parvirostris and E. spectabilis). This and a similar lowland speciation event between E. mesoleuca and the E. chiriquensis complex fell within a period of global warming [33-39] and concomitant sea level rises of up to $80 \mathrm{~m} \mathrm{[40]} \mathrm{which}$ led to pronounced marine incursions into the Río de la Plata Basin in the south and the Amazon in the north. Such marine incursions or the continuing spatio-temporal dynamics of Lago Amazonas further inland, or a combination thereof, were presumably the driving forces for these lowland speciation events.

The mid to late Pliocene from c. 4 MYA onwards sees the emergence and rapid differentiation of the "montane forest clade" (Figure 3), giving rise to a suite of highland species. This coincides with a period of rapid Andean uplift between 5 and 2 MYA [31]. The Central American mountains were colonized by $E$. frantzii immediately after the closure of the Panamanian isthmus at c. 3.5 MYA [41,42]. Starting around the same time, the Caribbean was invaded by E. fallax, E. cherriei and E. martinica, though we are unable to specify whether one or two colonization events were involved. Dispersal must certainly have played a role in the diversification of the montane clade, as neither the Caribbean islands nor the Venezuelan Tepuis (colonized by E. olivina) have ever been connected to the Andes. The Andes likely played a role in isolating the Chocó endemic E. brachyptera from cis-Andean E. chiriquensis around the late Pliocene.

\section{Conclusion}

Our ancestral reconstructions of habitat preferences in Elaenia reveal pronounced differences not only in the timing of the emergence of certain habitat preferences, but also in the frequency of habitat shifts. Savannah specialism has an early origin in the genus, which highlights the importance of this habitat in Neotropical Pliocene and late Miocene biogeography. Forest in old mountain ranges such as the Tepuis and the Brazilian Shield was colonized early on with limited subsequent in-situ differentiation, while the most important colonization event of montane forest was in conjunction with Pliocene Andean uplift and led to a rapid allopatric diversification. Riparian 
habitats may have played an important role in facilitating the colonization of new habitats by enabling birds to expand up the mountains along streams and to adapt to newly emerging montane forest habitat. We also confirm austral long-distance migration to be a labile trait in Neotropical songbirds.

\section{Methods \\ Sampling regime and laboratory techniques}

We investigated one mitochondrial coding gene region, $\mathrm{NADH}$ dehydrogenase subunit 2 (ND2), and one nuclear intron, $\beta$-fibrinogen intron 5 (Fib5). Tissue samples were obtained for all but one currently recognized species of Elaenia, as E. ridleyana, endemic to the tiny island of Fernando de Noronha in the Atlantic Ocean, was not available for inclusion. Sampling focussed on obtaining a large geographic and subspecific coverage of Elaenia species. In addition to the 64 specimens sampled in the present study, sequence data were sourced from the literature for a further nine samples (see Table 2), thereby totalling 18 species. Specimen information and Genbank accession numbers are provided in Table 2. For outgroup comparisons we used Capsiempis flaveola [43] (Genbank accession numbers

DQ294563

and

DQ294475

), as it has a close affinity to Elaenia [17].

Extraction and sequencing techniques followed Rheindt et al. [17]. ND2 sequences were obtained for all 73 ingroup samples, while the Fib5 dataset was restricted to 47 samples. Alignment and editing of sequences was carried out using SEQUENCHER v.4.1.4 (Gene Codes Corp., Ann Arbor, Michigan). Coding sequences were translated and checked for anomalous substitution patterns, such as double peaks and stop codons. All sequences were manually edited and assessed for deviant base composition.

\section{Phylogenetic analysis}

Phylogenetic analysis of the separate data partitions as well as the concatenated dataset was carried out using maximum parsimony (MP) and Bayesian inference (BI). Indels were excised from the dataset on account of their low number and short lengths, but the parsimonyinformative ones were later mapped onto the tree. For MP analysis, we ran heuristic searches (default settings activated unless otherwise specified) using the program PAUP* v4.0b10 [44]. Tree searches were unweighted as there was no evidence of saturation (see Results). PAUP* was also employed for estimating partition and sequence parameters. All PAUP* analyses involved 100 bootstrap replicates.

For BI analysis, the hierarchical likelihood ratio test implemented in the program MODELTEST 3.06 [45] was run to recover an appropriate evolutionary model for each partition (Table 4). MRBAYES 3.1 [46] was run with default settings (unless otherwise specified) using the basic parameters determined by MODELTEST, while allowing for the estimation of model-specific parameters such as base frequencies or gamma shape [p. 56 in ref [47]]. The analysis of the concatenated dataset was conducted with separate evolutionary model settings for each partition. BI searches employed Metropolis-coupled Markov chain Monte Carlo sampling with one cold and three heated chains running for 1 million generations with a sampling frequency of 100 . The burn-in period was determined graphically following Ronquist et al. [47] and samples within this period were discarded (Table 4). Subsequently, posterior probabilities were derived from the $50 \%$ majority rule consensus of all trees retained.

\section{Ancestral character state reconstruction}

Ecological parameters were mapped onto the tree topology derived from the concatenated dataset (with specieslevel lineages reduced to one representative) as discrete characters using life-history information from Ridgely and Tudor [15] and Hosner [16]. Transition rates between individual parameter states were also calculated. Four ecological parameters were mapped. (a) Breeding occurrence in forest interior (yes/no). Species that mainly breed in forest edge were not included; (b) Breeding occurrence in natural savannahs and cerrado vegetation (yes/no). Species ranging in similar open habitat of anthropogenic origin were not included. (c) At least regional breeding occurrence in riparian habitats such as gallery forest, Amazonian river-islands, riparian successional zones, Andean and pre-Andean streamside and similar habitats (yes/no). (d) Migratory status (austral long-distance migrants, partial/short-distance migrants or sedentary species). This character was frequently double-coded, since all species that have partially migratory populations are sedentary throughout most of their range, and one species (E. albiceps) includes both sedentary montane populations and austral long-distance migrants.

For state reconstruction of these parameters, we employed an MP-based approach [48] as implemented in the program MACCLADE[49]. MP analysis assumed unordered states. Character states were also mapped using the program MultiState in the computer package BAYESTRAITS[14]. The Bayesian method generates posterior probabilities for ancestral character states to gauge estimation reliability. BI analyses were run for 1,000,000 iterations with a tree sampling rate of 1,000 and a burn-in of 
50,000 iterations. We employed a uniform hyperprior to obtain a suitable prior for Bayesian runs assuming an exponential distribution. Posterior probabilities for character states were recorded for relevant nodes, and character transition rates were estimated.

\section{Molecular clock estimates}

PAUP* was used in conjunction with the evolutionary model specified by MODELTEST 3.06 for our ND2 partition (Table 4) to compute maximum-likelihood scores for the most likely tree under the enforcement of a molecular clock and under relaxed branch length assumptions. For computational efficiency the ND2 dataset was reduced to one representative per species-level lineage. Likelihood scores were compared with a $\chi^{2}$-test $(\mathrm{df}=20)$ to see whether they differed significantly. We refrained from using the concatenated dataset for this analysis, because the molecular clock rate used in this study (2\% divergence/MY) is based on mitochondrial DNA (see Discussion for rationale).

\section{Authors' contributions}

FER designed the study, carried out labwork and phylogenetic analyses and drafted the manuscript. LC assisted with the design of the study and contributed to the manuscript. JAN assisted with the design of the study and labwork and contributed to the manuscript. All authors read and approved the manuscript.

\section{Acknowledgements}

We would like to thank the following people at the following institutions for the provision of tissue samples: Donna Dittmann, Van Remsen and Robb Brumfield (Louisiana State University Museum of Natural Sciences, Baton Rouge, Louisiana), Nate Rice and Leo Joseph (Academy of Natural Sciences of Philadelphia, Pennsylvania), Mark Robbins and A. Townsend Peterson (University of Kansas Natural History Museum, Lawrence, Kansas), David Willard and Shannon Hackett (The Field Museum of Natural History, Chicago, Illinois), Paul Sweet (American Museum of Natural History, New York), Christopher Huddleston (Smithsonian National Museum of Natural History, Washington, D.C.), Cristina Miyaki (Laboratório de Genética e Evolução Molecular de Aves, São Paulo), and Jon Fjeldså (Zoological Museum, University of Copenhagen). This work was undertaken at the Population and Evolutionary Genetics Unit, Museum Victoria, which was established with the generous support of the lan Potter Foundation and Amersham Biosciences (now GE Healthcare). The first author was supported by the following grants: Joseph Grinnell Student Research Award 2004 awarded by the Cooper Ornithological Society; Sigma Xi Grant-in-Aid of Research 2004; Systematics Research Fund 2006 awarded by the Linnean Society; Museum Victoria 1854 Student Scholarship and University of Melbourne IPRS/MIRS Scholarships.

\section{References}

I. Ribas CC, Moyle RG, Miyaki CY, Cracraft J: The assembly of montane biotas: linking Andean tectonics and climatic oscillations to independent regimes of diversification in Pionus parrots. Proc $R$ Soc B 2007, 274:2399-2408.

2. Cadena $C D$, Klicka J, Ricklefs RE: Evolutionary differentiation in the Neotropical montane region: Molecular phylogenetics and phylogeography of Buarremon brush-finches (Aves, Emberizidae). Mol Phylogenet Evol 2007, 44:993-1016.

3. Brumfield RT, Edwards SV: Evolution into and out of the Andes: a Bayesian analysis of historical diversification in Thamnophilus antshrikes. Evolution 2007, 61 :346-367.

4. Ribas CC, Miyaki CY: Molecular systematics in Aratinga parakeets: species limits and historical biogeography in the solstitialis group, and the systematic position of Nandayus nenday. Mol Phylogenet Evol 2006, 30:663-675.

5. Weigt LA, Crawford AJ, Rand AS, Ryan MJ: Biogeography of the túngara frog Physalaemus pustulosus : a molecular perspective. Mol Ecol 2005, 14:3857-3876.

6. Aleixo A: Historical diversification of a terra-firme forest bird superspecies: a phylogeographic perspective on the role of different hypotheses of Amazonian diversification. Evolution 2004, 58:1303-1317.

7. Dick CW, Abdul-Salim K, Bermingham E: Molecular systematic analysis reveals cryptic tertiary diversification of a widespread tropical rain forest tree. Am Nat 2003, 162:691-703.

8. Dick CW, Roubik DW, Gruber KF, Bermingham E: Long-distance gene flow and cross-Andean dispersal of lowland rainforest bees (Apidae: Euglossini) revealed by comparative mitochondrial DNA phylogeography. Mol Ecol 2004, 13:3775-3785.

9. Burns KJ, Naoki K: Molecular phylogenetics and phylogeography of tanagers in the genus Tangara. Mol Phylogenet Evol 2004, 32:838-854.

10. Cheviron ZA, Capparella AP, Vuilleumier F: Molecular and phylogenetic relationships among the Geositta miners (Furnariidae) and biogeographic implications for avian speciation in Fuego-Patagonia. Auk 2005, I 22: I58- 174.

II. Chesser RT: Evolution in the high Andes: the phylogenetics of Muscisaxicola ground-tyrants. Mol Phylogenet Evol 2000, I5:369-380.

12. Voelker G: Dispersal, vicariance and clocks: historical biogeography and speciation in a cosmopolitan passerine genus (Anthus: Motacillidae). Evolution 1999, 53:1536-1552.

13. Arbogast BS, Drovetski SV, Curry RL, Boag PT, Seutin G, Grant PR, Grant BR, Anderson DJ: The origin and diversification of Galapagos mockingbirds. Evolution 2006, 60:370-382.

14. Pagel M, Meade A, Barker D: Bayesian estimation of ancestral character states on phylogenies. Syst Biol 2004, 53:673-684.

15. Ridgely RS, Tudor G: The Birds of South America. The Suboscine Passerines Volume II. Oxford: Oxford University Press; 1994.

16. Hosner PA: Genus Elaenia. In Handbook of the Birds of the World. Cotingas to Pipits and Wagtails Volume 9. Edited by: del Hoyo J, Elliott $A$, Christie DA. Barcelona: Lynx Edicions; 2004.

17. Rheindt FE, Norman JA, Christidis L: Phylogenetic relationships of tyrant-flycatchers (Aves; Tyrannidae), with an emphasis on the elaeniine assemblage. Mol Phylogenet Evol 2008, 46:88-10I. (DOI: 10.1016/j.ympev.2007.09.01I).

18. Zimmer JT: Studies of Peruvian birds. No. XXXVI. The genera Elaenia and Myiopagis. American Museum Novitates 194I, I I 08: I-23.

19. Traylor MA: Notes on tyrant-flycatchers (Aves: Tyrannidae). Fieldiana Zoology (New Series 13) 1982, I 338: I-22.

20. Joseph L, Wilke T, Alpers D: Independent evolution of migration on the South American landscape in a long-distnce temperate-tropical migratory bird, Swainson's flycatcher (Myiarchus swainsoni). J Biogeogr 2003, 30:925-937.

21. Lovette IJ: Mitochondrial dating and mixed support for the "2\% rule" in birds. Auk 2004, I 2 I: I-6.

22. García-Moreno J: Is there a universal mtDNA clock for birds? J Avian Biol 2004, 35:465-468.

23. Townsend Peterson A: Application of molecular clocks in ornithology revisited. J Avian Biol 2006, 37:541-544.

24. Pereira SL, Baker AJ: A mitogenomic timescale for birds detects variable phylogenetic rates of molecular evolution and refutes the standard molecular clock. Mol Biol Evol 2006, 23(9): $173 \mid-1740$.

25. Fleischer RC, Mclntosh CE, Tarr CL: Evolution on a volcanic conveyor belt: Using phylogenetic reconstructions and K-Arbased ages of the Hawaiian Islands to estimate molecular evolutionary rates. Mol Ecol 1998, 7:533-545.

26. Fleischer RC, Kirchman JJ, Dumbacher JP, Bevier L, Dove C, Rotzel NC, Edwards SV, Lammertink M, Miglia KJ, Moore WS: Mid-Pleis- 
tocene divergence of Cuban and North American ivorybilled woodpeckers. Biol Letters 2006, 2:466-469.

27. Shields GF, Wilson AC: Calibration of mitochondrial DNA evolution in geese. J Mol Evol 1987, 24:212-217.

28. Tarr CL, Fleischer RC: Mitochondrial-DNA variation and evolutionary relationships in the amakihi complex. Auk 1993, I I 0:825-83|.

29. Weir JT, Schluter D: Calibrating the avian molecular clock. Mol Ecol 2008, I7:232I-2328.

30. Campbell KE, Frailey CD, Romero-Pittman L: The Pan-Amazonian Ucayali Peneplain, late Neogene sedimentation in Amazonia, and the birth of the modern Amazon River system. Palaeogeogr Palaeoclimatol Palaeoecol 2006, 239:166-219.

31. Gregory-Wodzicki KM: Uplift history of the Central and Northern Andes: A review. GSA Bulletin 2000, I I 2: 109|-I I05.

32. Gregory-Wodzicki KM: A late Miocene subtropical-dry flora from the northern Altiplano, Bolivia. Palaeogeogr Palaeoclimatol Palaeoecol 2002, 180:331-348.

33. Barrett PJ, Adams CJ, Mclntosh WC, Swisher CC, Wilson GS: Geochronological evidence supporting Antarctic deglaciation three million years ago. Nature 1992, 359:816-8I8.

34. Barron JA: Diatom constraints on the position of the Antarctic polar front in the middle part of the Pliocene. Mar Micropaleont 1996, 27:195-204.

35. Dowsett H, Barron J, Poore R: Middle Pliocene sea surface temperatures: a global reconstruction. Mar Micropaleont 1996, 27:13-25.

36. Fleming RF, Barron JA: Evidence of Pliocene Nothofagus in Antarctica from Pliocene marine sedimentary deposits (DSDP Site 274). Mar Micropaleont 1996, 27:227-236.

37. Thompson RS, Fleming RF: Middle Pliocene vegetation: reconstructions, paleoclimatic inferences, and boundary conditions for climate modeling. Mar Micropaleont 1996, 27:27-49.

38. Molnar P, Cane MA: EI Niño's tropical climate and teleconnections as a blueprint for pre-Ice-Age climates. Paleoceanography 2002, 17:1-II.

39. Ashworth AC, Thompson FC: A fly in the biogeographic ointment. Nature 2003, 423: 135-136.

40. Haq BU, Hardenbol J, Vail PR: Chronology of fluctuating sea levels since the Triassic. Science 1987, 235: | I56- I 67.

41. Keigwin L: Isotopic paleoceanography of the Caribbean and East Pacific: role of Panama uplift in late Neogene time. Science 1982, 21 7:350-353.

42. Coates AG, Jackson JBC, Collins LS, Cronin TM, Dowsett HJ, Bybell LM, Jung P, Obando JA: Closure of the Isthmus of Panama: The near-shore marine record of Costa Rica and western Panama. GSA Bulletin 1992, 104:8|4-828.

43. Tello JG, Bates JM: Molecular phylogenetics of the tody-tyrant and flatbill assemblage of tyrant flycatchers (Tyrannidae). Auk 2007, I24: I34-I54.

44. Swofford DL: PAUP*: Phylogenetic analysis using parsimony (* and other methods), version 4.0 Sunderland, Massachusetts: Sinauer Associates; 2002.

45. Posada D, Crandall KA: MODELTEST: testing the model of DNA substitution. Bioinformatics 1998, 14:817-8|8.

46. Ronquist F, Huelsenbeck JP: MRBAYES 3: Bayesian phylogenetic inference under mixed models. Bioinformatics 2003, 19:1572-1574.

47. Ronquist F, Huelsenbeck JP, Mark P van der: MrBayes 3.I Manual 2005 [http://mrbayes.csit.fsu.edu/manual.php].

48. Maddison WP: A method for testing the correlated evolution of two binary characters: are gains and losses concentrated on certain branches of a phylogenetic tree. Evolution 1990, 44:539-557.

49. Maddison DR, Maddison WP: MacClade: analysis of phylogeny and character evolution. Vers. 4.0 Sunderland, Massachusetts: Sinauer Associates; 2000.
Publish with Biomed Central and every scientist can read your work free of charge

"BioMed Central will be the most significant development for disseminating the results of biomedical research in our lifetime. "

Sir Paul Nurse, Cancer Research UK

Your research papers will be:

- available free of charge to the entire biomedical community

- peer reviewed and published immediately upon acceptance

- cited in PubMed and archived on PubMed Central

- yours - you keep the copyright
BioMedcentral 